\title{
Sulfonated Alumina: A Suitable Catalyst for Furfural Biomass Building-Block Valorization Through Multicomponent Reactions
}

\section{Alúmina sulfonada: un catalizador adecuado para la valorización de componentes básicos de biomasa del furfural a través de reacciones multicomponente}

\author{
E. Nope ${ }^{1}$, D. Ruiz ${ }^{1}$, A. Sathicq ${ }^{1}$, and G. Romanelli ${ }^{1,2}$
}

\begin{abstract}
Sulfonated alumina was synthetized and tested for the first time in furfural valorization through a multicomponent reaction for the preparation of a nitrogenated heterocyclic compound containing the furan substructure. Ten polysubstituted heterocycles, belonging to the dihydropyrimidinones (thiones) and 1,4-dihydropyridines, were obtained with very good yields $(70 \%-85 \%)$ using the tandem methodology and green reaction conditions. The catalyst was easily separated from the reaction medium, giving a high yield in the reusability studies. Green metrics were analyzed in order to consider the reaction suitability.
\end{abstract}

Keywords: furfural valorization, sulfonated silica, multicomponent reaction, nitrogenated heterocyclic compounds, green metrics analysis

\section{Resumen}

La alúmina sulfonada se sintetizó y ensayó por primera vez en la valorización del furfural mediante una reacción multicomponente para la preparación de un compuesto heterocíclico nitrogenado que contiene la subestructura de furano. Se obtuvieron diez heterociclos polisustituidos, pertenecientes a las dihidropirimidinonas (tiones) y 1,4-dihidropiridinas, con muy buenos rendimientos (70\% - 85\%) utilizando la metodología tándem y las condiciones de reacción verde. El catalizador se separó fácilmente del medio de reacción, dando un alto rendimiento en los estudios de reutilización. Se analizaron las métricas verdes para considerar la idoneidad de la reacción.

Palabras clave: valorización de furfural, sílice sulfonada, reacción multicomponente, compuestos heterocíclicos nitrogenados, análisis de métricas verdes

Recepción: 11-jun-2020

Aceptación: 30-ago-2020

\footnotetext{
${ }^{1}$ Departamento de Química, Facultad de Ciencias Exactas, Centro de Investigación y Desarrollo en Ciencias Aplicadas “Dr. J. J. Ronco" (CINDECA), La Plata, Argentina.

${ }^{2}$ Centro de Investigaciones en Sanidad Vegetal (CISaV), Curso de Química Orgánica, FCAyF, La Plata, Buenos Aires, Argentina. Autor de correspondencia: gpr@quimica.unlp.edu.ar
} 


\section{Introduction}

The demand for a suitable approach to chemical processes has encouraged the use of recyclable solid acids as substitutes of unrecyclable mineral liquid acids, such as: $\mathrm{H}_{2} \mathrm{SO}_{4}, \mathrm{HCl}$ or $\mathrm{HF}$. The solid acid materials can be easily separated from the reaction mixture by means of centrifugation, decantation or filtration; as a result, the catalyst can be reused. The development of suitable heterogeneous catalysts to facilitate different organic transformations has been an interesting area of research in recent decades. In many cases the solid catalyst can be used and reused without appreciable loss of its catalytic activity [1].

H. Patel and col./et al. reviewed the utilization of several novel heterogeneous catalysts and their use in organic synthesis, for example, alumina sulfuric acid (ASA), tungstate sulfuric acid (TSA), molybdate sulfuric acid (MSA), and xanthan sulfuric acid (XSA) [2]. These materials are economical, efficient, and compatible with the environment. Particularly, they described the use of alumina sulfuric acid, obtained by the reaction between chlorosulfonic acid and activated neutral alumina in the synthesis of several organic compounds such as benzimidazoles, quinoxalines, nitration of aromatic compounds, synthesis of 2,5-disubstituted 1,3,4oxadiazoles, dithioacetalization, ortho-silylation of alcohols, oximes and phenols, Biginelli-type condensation reaction, and Pechmann condensation [2].

On the other hand, due to the great demand for biorenewable resources as a different feedstock for the synthesis of bulk chemicals, furfural has gained considerable attention.

Biofuran aldehydes, especially furfural, which are derived from the dehydration of $\mathrm{C}_{5}$ sugars, are a useful platform molecule used in the synthesis of chemical (furfuryl alcohol, tetrahydrofuran, $\mathrm{N}$ alkyl pyrrolidones, biphenolic acid, and furoic acid), liquid fuels and additives (levulinic and valeric acid esters, $\gamma$-valerolactone, and 2-methyl tetrahydrofuran), and other suitable materials [3].

Another new challenge in the synthesis of biobased materials and intermediates is the transformation of monosaccharides or their derivatives (furfural) into heterocycles via multicomponent reactions (MCR). These reactions are synthetic methodologies in which three or more reactants are put together in a simple vessel to form the product [4].

The remarkable characteristic of MCRs is that the unique reaction product contains almost all portions of substrates, generating almost no secondary products. Thus, MCRs have been widely studied in many fields such as the design of new drugs and combinatorial chemistry [4].

Two relevant families of compounds that can be obtained by multicomponent procedures are dihydropyrimidinones (thiones) and 1,4dihydropyridines. They have a pyrimidine and pyridine core, respectively, which is a relevant pharmacophore used in the design of new drugs. Both compound families have a broad range of bioactivity that includes calcium channel inhibition, anticancer, anti-inflammatory, antimicrobial, antioxidant, neuroprotective, antidiabetic, antianginal, analgesic, antiviral, antifungal, and anti-ischemic effects [5-14].

Due to the relevance of these families of compounds, the literature reports on different methodologies for their synthesis. The most popular method for dihydropyrimidinone synthesis is the Biginelli reaction, a multicomponent methodology involving the condensation of aldehyde, $\beta$-ketoester, and urea (or thiourea) assisted by an acid catalyst [15].

A variety of new catalytic materials that include Lewis and Bronsted acids have been mentioned in the literature, for example, alumina-supported $\mathrm{MoO}_{3}$ [16], antimony (III) chloride [17], iron (III) trifluoroacetate and trifluoromethanesulfonate [18], PSSA [19], silica sulfuric acid [20], $\mathrm{H}_{3} \mathrm{PW}_{12} \mathrm{O}_{40}$ [21], zeolite-supported heteropolyacids (HPA) [22], among others.

The typical procedure leading to 1,4dihydropyridines is the Hantzsch reaction. It is a one-pot condensation of $\beta$-dicarbonylic compounds with aldehydes and ammonia, which can also be assisted by different catalysts such as heteropolyacids [23], iodine [24], hydrotalcites [25], silica sulfuric acid [26], enzymes [27], $\mathrm{H}_{2} \mathrm{O}-\mathrm{PEG}$ [28], among others. 
In this paper we report on the use of sulfonated alumina $\left(\mathrm{Al}_{2} \mathrm{O}_{3}-\mathrm{SO}_{3} \mathrm{H}\right)$, a suitable catalyst for the synthesis of several dihydropyridines (thiones) and 1,4dihydropyridines containing the furfural substructure. Figures 1 and 2 show two representative examples.

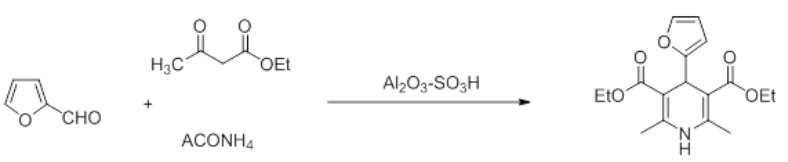

Figure 1. 1,4-Dihydropyridine synthesis using furfural as building block.

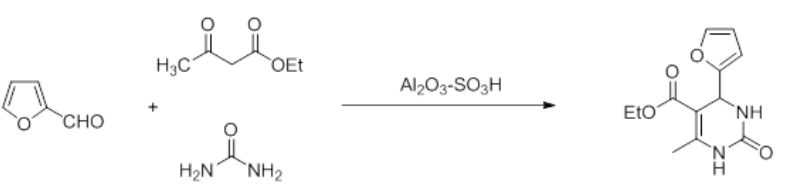

Figure 2. Dihydropyrimidinone synthesis using furfural as building block.

\section{Experimental}

\subsection{General procedures}

Melting points were measured in an open capillary using Buchi melting point apparatus and were uncorrected. ${ }^{1} \mathrm{H}$ NMR and ${ }^{13} \mathrm{C}$ NMR spectra were recorded on a Bruker AM-400 spectrometer (400 and $100 \mathrm{MHz}$, respectively) using TMS as internal standard. Reactions were monitored by thin layer chromatography on $0.2 \mathrm{~mm}$ silica gel F-252 (Merck) plates and in some cases by gas chromatography using a Shimadzu GC 2010 instrument. All ßketo esters, aldehydes, amines, urea/thiourea and ammonium acetate derivatives were obtained from Aldrich Chemical Co. and used without further purification, with the exception of benzaldehyde, which was distilled in vacuo prior to use. All solid components were employed as grained powders. All synthetized compounds were known, and the melting point and NMR spectrum of selected molecules were added in the additional material sections.

\subsection{Catalyst synthesis}

For the synthesis of $\mathrm{Al}_{2} \mathrm{O}_{3}-\mathrm{SO}_{3} \mathrm{H}, 5 \mathrm{~g}$ of alumina $\left(\mathrm{Al}_{2} \mathrm{O}_{3}\right), 100 \mathrm{~mL}$ of dry toluene, and $1.15 \mathrm{~mL}$ of 3-mercaptopropyltrimethoxysilane (MPTMS) were mixed and refluxed for $24 \mathrm{~h}$, under constant stirring. Subsequently, mercaptopropyl groups were oxidized to sulfonic groups $\left(-\mathrm{SO}_{3} \mathrm{H}\right)$ with the addition of excess hydrogen peroxide, which was kept under stirring for $24 \mathrm{~h}$ at room temperature. The final solid was washed several times with acetone and dried at 393 K [29].

\subsection{Catalyst characterization}

The material was characterized by acidity and surface measurements (SBET). The complete characterization of the material will be reported in a future work. The textural properties, which were determined from nitrogen adsorption-desorption at $77 \mathrm{~K}$, were measured on Micromeritics ASAP 2020 equipment. Samples were previously evacuated at $623 \mathrm{~K}$ for $16 \mathrm{~h}$. The surface area was calculated using a multipoint Brunauer-Emmett-Teller model.

The pore size distribution was obtained by the $\mathrm{BJH}$ model, and the total pore volume was estimated at a relative pressure of 0.99 . The acid capacity was determined by titration with $0.01 \mathrm{M} \mathrm{NaOH}$ (aq.) [30]. In a typical experiment, $0.1 \mathrm{~g}$ of solid was added to $10 \mathrm{~mL}$ of deionized water. The resulting suspension was allowed to equilibrate and thereafter was titrated by dropwise addition of $0.01 \mathrm{M} \mathrm{NaOH}$ solution using phenolphthalein as $\mathrm{pH}$ indicator.

\subsection{General procedure for synthesis of 1,4- dihydropyridine compounds using furfural, ethyl acetoacetate, and ammonium acetate as substrates}

Ethyl acetoacetate (130 mg, $1 \mathrm{mmol})$, furfural (48 $\mathrm{mg}, 1 \mathrm{mmol}$ ), ammonium acetate (52 $\mathrm{mg}, 1.2 \mathrm{mmol}$ ), and the catalyst $(35 \mathrm{mg}$ ) were thoroughly mixed and then heated at $80{ }^{\circ} \mathrm{C}$ for $2 \mathrm{~h}$. The progress of the reaction was monitored by TLC. After completion of the reaction, acetone was added $(3 \times 1 \mathrm{~mL})$, and the catalyst was filtered. The extracts were combined and dried with anhydrous sodium sulfate and concentrated in vacuum $\left(40{ }^{\circ} \mathrm{C}\right)$. The crude product was recrystallized from methanol, ethanol or isopropanol to give pure 1,4-dihydropyridine. 
2.5 General procedure for synthesis of 3,4dihydropyrimidinone compounds using furfural, ethyl acetoacetate and urea as substrates

Ethyl acetoacetate (130 mg, $1 \mathrm{mmol})$, furfural (96 $\mathrm{mg}, 1 \mathrm{mmol})$, urea $(90 \mathrm{mg}, 1.5 \mathrm{mmol})$, and the catalyst $(35 \mathrm{mg}$ ) were thoroughly mixed and then heated at $80{ }^{\circ} \mathrm{C}$ for $2.5 \mathrm{~h}$. The progress of the reaction was monitored by TLC. After completion of the reaction, acetone was added $(3 \times 1 \mathrm{~mL})$, and the catalyst was filtered. The extracts were combined and dried with anhydrous sodium sulfate and concentrated in vacuum $\left(40{ }^{\circ} \mathrm{C}\right)$. The crude product was recrystallized from methanol, ethanol or isopropanol to give pure 3,4-dihydropyrimidinone.

\subsection{Recycling of the catalyst in both synthesis}

The reuse of the catalyst was checked in five consecutive batches after the first one; the catalysts showed almost constant activity. The catalyst was separated, washed in polar media such as acetone (3 $\mathrm{x} 1 \mathrm{~mL})$, dried under vacuum $\left(50{ }^{\circ} \mathrm{C}\right)$, and reused, repeating this procedure.

\section{Results and discussion}

\subsection{Catalytic synthesis and characterization}

Functionalized alumina $\left(\mathrm{Al}_{2} \mathrm{O}_{3}-\mathrm{SO}_{3} \mathrm{H}\right)$ was synthetized, and the most relevant data are summarized in Table 1, which lists the textural properties obtained from the adsorption-desorption isotherms of $\mathrm{N}_{2}$ at $77 \mathrm{~K}$ and the acid capacity of the synthesized material $\mathrm{Al}_{2} \mathrm{O}_{3}-\mathrm{SO}_{3} \mathrm{H}$. It can be seen that the surface area of $\mathrm{Al}_{2} \mathrm{O}_{3}\left(\mathrm{~S}_{B E T}=186 \mathrm{~m}^{2} / \mathrm{g}\right)$ decreases with the functionalization of sulfonic groups, because the textural properties of porous materials decrease when treated with organosilane compounds [30], which could be related to the distribution of sulfonic groups within the porous structure. In addition, this material has high acid capacity, which makes it a highly promising material for reactions that involve acid catalysis.
Table 1. Textural properties and acid capacity of $\mathrm{Al}_{2} \mathrm{O}_{3}-\mathrm{SO}_{3} \mathrm{H}$

\begin{tabular}{|c|c|c|c|c|}
\hline Catalyst & $\begin{array}{c}\mathbf{S}_{B E T} \\
\left(\mathbf{m}^{2} \mathbf{g}^{-1}\right)\end{array}$ & $\begin{array}{c}\text { Pore volume } \\
\left(\mathrm{cm}^{3} \mathbf{g}^{-1}\right)\end{array}$ & $\begin{array}{c}\text { Pore size } \\
\quad(\mathbf{n m})\end{array}$ & $\begin{array}{c}\begin{array}{c}\text { Acid } \\
\text { capacity } \\
(\mathbf{m m o l}\end{array} \\
\left.\mathbf{H}^{+} / \mathbf{g}\right)\end{array}$ \\
\hline$\gamma-\mathrm{Al}_{2} \mathrm{O}_{3}$ & 250 & 0.8 & 9 & - \\
\hline $\mathrm{Al}_{2} \mathrm{O}_{3}-\mathrm{SO}_{3} \mathrm{H}$ & 186 & 0.32 & 6.8 & 26.4 \\
\hline
\end{tabular}

\subsection{Catalytic tests}

\subsubsection{A-1,4-Dihydropyridine}

Initially, the optimum reaction conditions for 1,4dihydropyridine synthesis were evaluated employing furfural, ethyl acetoacetate, and ammonium (ratio $1: 2: 1.3$, respectively) in solvent-free conditions at $80{ }^{\circ} \mathrm{C}$ for $2 \mathrm{~h}$. to obtain the corresponding dihydropyridine (Scheme A).

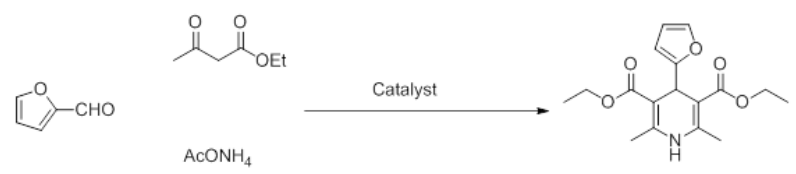

Figure 3. Scheme A. Hantzsch reaction using furfural as building block.

In an experiment, without the presence of catalyst, a very poor yield (18\%) of DHP was obtained (Table 2 , entry 1). Similarly, a poor reaction yield was obtained when the support $\left(\mathrm{Al}_{2} \mathrm{O}_{3}\right)$ (Table 2, entry 2) was used as catalyst, under the same reaction conditions (25\%). After that the $\mathrm{Al}_{2} \mathrm{O}_{3}-\mathrm{SO}_{3} \mathrm{H}$ catalyst was checked under the same reaction conditions (Table 2, entry 3 ) and a very good yield of DHP was obtained, $85 \%$, indicating that the presence of one material with acidic properties was necessary to improve the reaction yields.

Another important issue to review in these tests, due to the material cost, is the amount of the $\mathrm{Al}_{2} \mathrm{O}_{3}-\mathrm{SO}_{3} \mathrm{H}$ catalyst (Table 2, entries 3-6). It can be seen that $25 \mathrm{mg}$ of $\mathrm{Al}_{2} \mathrm{O}_{3}-\mathrm{SO}_{3} \mathrm{H}$ is the appropriate amount to give very good yields (Table 2 , entry $3,85 \%$ ) and no relevant changes were found when the amount of catalyst doubled $(50 \mathrm{mg}$ ) (Table 2 , entry $6,87 \%$ ).

The temperature effect on the yield of DHP is shown in Table 2, entries 3, 7, 8, 9, and 10. Five tests were performed at $20,40,60,80$, and $100{ }^{\circ} \mathrm{C}$ by 
using $\mathrm{Al}_{2} \mathrm{O}_{3}-\mathrm{SO}_{3} \mathrm{H}$ as catalyst. The results showed the best yield at $80{ }^{\circ} \mathrm{C}(85 \%$, Table 2, entry 3$)$.

No reaction was detected when the test was performed at room temperature $\left(20^{\circ} \mathrm{C}\right)$ (Table 3, entry 7). The selectivity in all temperature conditions was $100 \%$, and no secondary products were detected by GC and TLC analysis. However, at $100^{\circ} \mathrm{C}$ the reaction mixture became considerably darker, the yield of the reaction dropped significantly, and TLC revealed the formation of numerous secondary products.

The reaction time was also tested at the selected optimal reaction temperature of $80^{\circ} \mathrm{C}$, using four different times of 30,60,120, and $180 \mathrm{~min}$ (Table 2, entries 3,11, 12, and 13, respectively). A good yield $(70 \%)$ was obtained at $60 \mathrm{~min}$ of reaction (Table 2, entry 12), reaching the optimal yields/yield at 120 $\mathrm{h}(85 \%$, Table 2 , entry 3$)$, without any variation at longer reaction times such as $180 \mathrm{~h}(84 \%$, Table 2 , entry 13$)$.

The catalyst reusability was also analyzed under the best reaction conditions $\left(80^{\circ} \mathrm{C}, 120 \mathrm{~min}\right.$, solventfree conditions, using $25 \mathrm{mg}$ of the catalyst, over six consecutive runs). The recovered catalyst was washed with ethanol $(2 \times 1.5 \mathrm{~mL})$ and dried at $20^{\circ} \mathrm{C}$ in vacuum. The results are listed in Table 2 , entries $3,14,15,16,17$, and 18 . No appreciable variations of the yields were observed when the catalyst was reused five consecutive times. The loss of catalyst mass after the six runs was only $10 \%$.

To test the possible catalyst solubilization, an additional experiment was performed. The catalyst sample $(25 \mathrm{mg})$ was refluxed in ethanol (solvent used in the isolated reaction products $(5 \mathrm{~mL})$ ) for $4 \mathrm{~h}$, filtered at high temperature $\left(60^{\circ} \mathrm{C}\right)$, and dried in vacuum till constant weight. The activity of the treated catalyst was the same as that of the fresh catalyst ( $85 \%$ yield in $120 \mathrm{~min}$ ).

\subsubsection{B-1,3-Dihydropyrimidinones}

In a similar way to the 1,4-dyhidropyridine optimization synthesis, we studied the Biginelli reaction to obtain 1,3-dihydropyrimidinones. The optimum reaction conditions were evaluated using furfural, ethyl acetoacetate, and urea as test reaction substrates (ra-
Table 2. Effect of different reaction parameters on 1,4-DHP $(\%)^{\mathrm{a}}$

\begin{tabular}{|c|c|c|c|c|c|}
\hline Entry & Catalyst & $\begin{array}{c}\text { Amount of } \\
\mathrm{Al}_{2} \mathrm{O}_{3^{-}} \\
\mathrm{SO}_{3} \mathrm{H}(\mathrm{mg})\end{array}$ & $\begin{array}{l}\text { Temperature } \\
\left({ }^{\circ} \mathrm{C}\right)\end{array}$ & $\begin{array}{l}\text { Time } \\
(\mathbf{m})\end{array}$ & $\begin{array}{c}\text { Yield } \\
(\%)\end{array}$ \\
\hline 1 & None & - & 80 & 120 & 18 \\
\hline 2 & $\mathrm{Al}_{2} \mathrm{O}_{3}$ & - & 80 & 120 & 25 \\
\hline 3 & $\mathrm{Al}_{2} \mathrm{O}_{3}-\mathrm{SO}_{3} \mathrm{H}$ & 25 & 80 & 120 & 85 \\
\hline 4 & & 5 & 80 & 120 & 32 \\
\hline 5 & & 10 & 80 & 120 & 58 \\
\hline 6 & & 50 & 80 & 120 & 87 \\
\hline 7 & & 25 & 20 & 120 & - \\
\hline 8 & & 25 & 40 & 120 & 34 \\
\hline 9 & & 25 & 60 & 120 & 67 \\
\hline 10 & & 25 & 100 & 120 & 70 \\
\hline 11 & & 25 & 80 & 30 & 41 \\
\hline 12 & & 25 & 80 & 60 & 70 \\
\hline 13 & & 25 & 80 & 180 & 84 \\
\hline 14 & & 25 & 80 & 120 & 85 \\
\hline 15 & & 25 & 80 & 120 & 85 \\
\hline 16 & & 25 & 80 & 120 & 84 \\
\hline 17 & & 25 & 80 & 120 & 82 \\
\hline 18 & & 25 & 80 & 120 & 82 \\
\hline
\end{tabular}

Note: Reaction conditions: furfural (96 mg); ethyl acetoacetate ( $2 \mathrm{mmol}$ ); ammonium acetate (100 mg, $1.2 \mathrm{mmol}$ ); catalyst 25 $\mathrm{mg}$; solvent-free; stirring. ${ }^{\mathrm{a}}$ Pure product. Catalyst reusability, entries 14-18.

tio $1: 1: 1.5$, respectively) in solvent-free conditions (Scheme B).

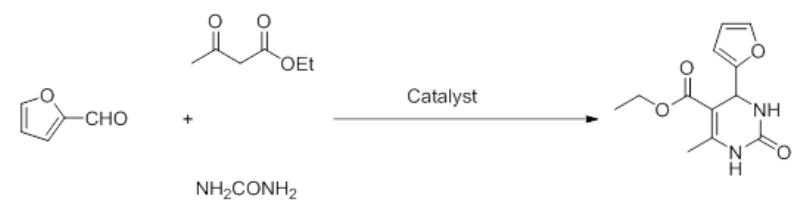

Figure 4. Scheme B. Biginelli reaction using furfural as building block

Table 3 lists the different reaction conditions including temperature, reaction time, and catalyst amount. As shown in Table 3, entry 3, the best reaction conditions were: catalyst: $50 \mathrm{mg}$, reaction time: $180 \mathrm{~min}$, and temperature: $80{ }^{\circ} \mathrm{C}$. It is important to note that at $100{ }^{\circ} \mathrm{C}$ several unidentified secondary products were detected by GC and TLC, 
and at $120{ }^{\circ} \mathrm{C}$ urea decomposed to ammonia, and the Hantzsch 1,4-dihydropyridine product began to be detected. Similarly, to the 1,4-dihydropyridine synthesis, the catalyst was recycled and reused for five times. The results are listed in Table 3, entries $3,14,15,16,17$, and 18 . No appreciable variations of the yields were observed when the catalyst was reused five consecutive times. The loss of catalyst mass after the six runs was only $14 \%$.

Table 3. Effect of different reaction parameters on 1,3-DHP $(\%)^{\mathrm{a}}$

\begin{tabular}{|c|c|c|c|c|c|}
\hline Entry & Catalyst & $\begin{array}{c}\text { Amount of } \\
\mathrm{Al}_{2} \mathrm{O}_{3} \mathrm{SO}_{3} \mathrm{H} \\
(\mathbf{m g})\end{array}$ & $\begin{array}{l}\text { Temperature } \\
\left({ }^{\circ} \mathrm{C}\right)\end{array}$ & $\begin{array}{l}\text { Time } \\
(\mathbf{m})\end{array}$ & $\begin{array}{c}\text { Yield } \\
(\%)\end{array}$ \\
\hline 1 & - & - & 80 & 180 & 7 \\
\hline 2 & $\mathrm{Al}_{2} \mathrm{O}_{3}$ & - & 80 & 180 & 18 \\
\hline 3 & $\mathrm{Al}_{2} \mathrm{O}_{3} \mathrm{SO}_{3} \mathrm{H}$ & 50 & 80 & 180 & 73 \\
\hline 4 & & 10 & 80 & 180 & 31 \\
\hline 5 & & 25 & 80 & 180 & 65 \\
\hline 6 & & 100 & 80 & 180 & 71 \\
\hline 7 & & 50 & 20 & 180 & - \\
\hline 8 & & 50 & 40 & 180 & 34 \\
\hline 9 & & 50 & 60 & 180 & 67 \\
\hline 10 & & 50 & 100 & 180 & 70 \\
\hline 11 & & 50 & 120 & 180 & 55 \\
\hline 12 & & 50 & 80 & 60 & 43 \\
\hline 13 & & 50 & 80 & 120 & 65 \\
\hline 14 & & 50 & 80 & 240 & 73 \\
\hline 15 & & 25 & 80 & 120 & 72 \\
\hline 16 & & 25 & 80 & 120 & 71 \\
\hline 17 & & 25 & 80 & 120 & 71 \\
\hline 18 & & 25 & 80 & 120 & 71 \\
\hline 19 & & 25 & 80 & 120 & 69 \\
\hline
\end{tabular}

Note: Reaction conditions: furfural (96 mg, $1 \mathrm{mmol}$ ); ethyl acetoacetate (130 mg, $1 \mathrm{mmol})$; urea (90 mg, $1.5 \mathrm{mmol}$ ); catalyst $50 \mathrm{mg}$; solvent-free; stirring. ${ }^{\text {a }}$ Pure product.

\subsubsection{Synthesis of 1,4-dihydropyridines}

Once the optimal reaction conditions for the synthesis of a 1,4-dihydropyridine were established, we explored the catalytic activity of $\mathrm{Al}_{2} \mathrm{O}_{3}-\mathrm{SO}_{3} \mathrm{H}$ for different substrates to show the generality of the optimized procedure. In all cases furfural was used as building block, and to obtain molecular diversity we employed different 1,3-dicarbonyl compounds and ammonia sources.

The 1,3-dicarbonyl compounds used were: ethyl acetoacetate, methyl acetoacetate, 2,4-pentanodione, cyclohexane 1,3-dione, 5,5 dimethyl cyclohexane 1,3-dione, and 3-oxobutanamide, and the ammonia sources were ammonium acetate and aniline. The results are listed in Table 4. The experiments were carried out under solvent-free conditions, in the presence of $25 \mathrm{mg}$ of catalyst. The reactions were completed within $120 \mathrm{~min}$ at $80{ }^{\circ} \mathrm{C}$. Five 1,4-dihydropyridines were obtained with very good yields. In all cases, the desired products were obtained with high selectivity, almost free of secondary products.

\subsubsection{Synthesis of 1,3-dihydropyrimidinones}

Similarly, the optimal reaction conditions for the synthesis of a 1,3-dihydropyrimidinone were applied to different substrates to show the generality of the optimized procedure, using $\mathrm{Al}_{2} \mathrm{O}_{3}-\mathrm{SO}_{3} \mathrm{H}$. In all cases furfural was used as building block, and we employed different 1,3-dicarbonyl compounds and urea or thiourea as nitrogen source. The results are listed in Table 5. The experiments were carried out under solvent-free conditions, in the presence of 50 $\mathrm{mg}$ of catalyst. The reactions were completed within $180 \mathrm{~min}$ at $80{ }^{\circ} \mathrm{C}$. Five 1,3 -dihydropyrimidinones were obtained with very good yields. In all cases, the desired products were obtained with high selectivity, almost free of secondary products. In entries 3 and 4 we used thiourea as nitrogen source, and in these cases the corresponding 1,3-dihydropyrimidinthiones were obtained. As in entries $7 \mathrm{~b}$ and $8 \mathrm{~b}$, using 5-hydroximethylfurfural, another building block obtained from biomass, the corresponding 1,3-dihydropyrimidinones were obtained with good yields.

Atom economy (AE), E-factor (E), reaction mass efficiency (RME), and material recovery parameter (MRP) were measured in order to quantify the "greenness" of the technology. Results are given in Tables 4 and 5. A comparison with modern classic synthetic methods for dihydropyrimidinones and dihydropyridines [31, 32] gives very good 
Table 4. 1,4-Dihydropyridine synthesis using furfural as building block

\begin{tabular}{|c|c|c|c|c|c|c|c|}
\hline Entry & $\mathrm{N}$-source & Product & E Factor & Yield (\%) & $\mathrm{AE}(\%)$ & RME & MRP \\
\hline $1 \mathrm{a}$ & $\mathrm{AcONH}_{4}$ & & 17.47 & 85 & 73.67 & 0.61 & 0.10 \\
\hline $2 a$ & $\mathrm{AcONH}_{4}$ & & 19.88 & 82 & 71.85 & 0.57 & 0.09 \\
\hline 3a & $\mathrm{AcONH}_{4}$ & & 24.42 & 75 & 69.44 & 0.50 & 0.09 \\
\hline $4 a$ & & & 15.22 & 79 & 77.60 & 0.67 & 0.11 \\
\hline $5 a$ & & & 19.73 & 71 & 74.83 & 0.49 & 0.10 \\
\hline
\end{tabular}

Note: Reaction conditions: furfural (1 mmol); 1,3-dicarbonyl compound (2 mmol); ammonia source (1.5 mmol); catalyst, $25 \mathrm{mg}$; temperature, $80^{\circ} \mathrm{C}$; time, $120 \mathrm{~min}$; solvent-free; stirring.

parameters (Figures 4 and 5).

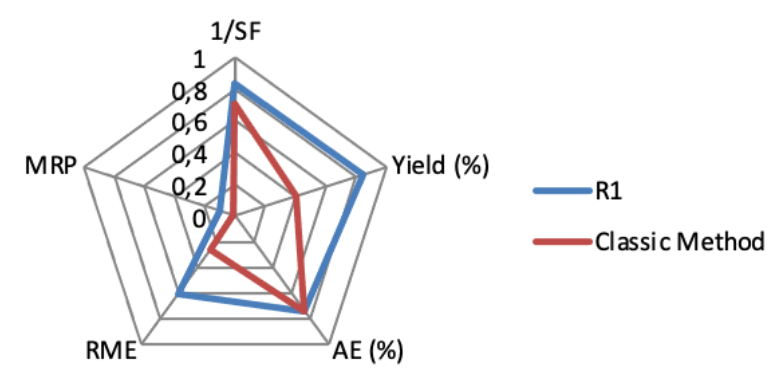

Figure 5. Comparison of green parameters of preparation of dihydropyridines with the classic synthesis method.

\section{Conclusion}

We prepared an $\mathrm{Al}_{2} \mathrm{O}_{3}-\mathrm{SO}_{3} \mathrm{H}$ functionalized catalyst and examined its catalytic activity for the synthesis of several 3,4-dihydropyrimidinone and 1,4dihydropyridine derivatives, using furfural (a building block present in vegetal biomass). The catalyst shows an environmentally friendly character, and its recyclability helps in the development of a greener methodology. Moreover, the different procedures

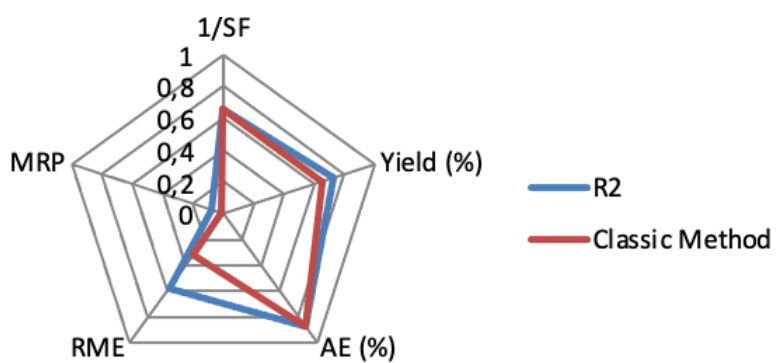

Figure 6. Comparison of green parameters of preparation of dihydropyrimidinones with the classic synthesis method.

offer several advantages including elevated yields, operational simplicity, environmentally friendly reaction conditions, and avoidance of toxic compounds.

\section{Acknowledgments}

This work was supported by Consejo Nacional de Investigaciones Científicas y Técnicas, Agencia Nacional de Promoción Científica y Tecnológica, Universidad Nacional de La Plata, and ERANET-LAC-1. AGS and GPR are members of CONICET. 
Table 5. 1,3-Dihydropyrimidinone synthesis using furfural as building block

\begin{tabular}{|c|c|c|c|c|c|c|}
\hline Entry & Product & $\mathrm{E}$ factor & Yield (\%) & $\mathrm{AE}(\%)$ & RME & MRP \\
\hline $1 b$ & & 28.81 & 70 & 86.76 & 0.55 & 0.08 \\
\hline $2 b$ & & 26.08 & 73 & 87.41 & 0.58 & 0.08 \\
\hline $3 \mathbf{b}$ & & 29.10 & 65 & 87.50 & 0.50 & 0.08 \\
\hline $4 b$ & & 25.98 & 69 & 88.08 & 0.54 & 0.09 \\
\hline $5 b$ & & 30.47 & 71 & 85.94 & 0.55 & 0.07 \\
\hline
\end{tabular}

Note: Reaction conditions: furfural (1 mmol); 1,3-dicarbonyl compound (1 mmol); ammonia source (urea or thiourea) (1.5 mmol); catalyst $50 \mathrm{mg}$; solvent-free; stirring.

\section{References}

[1] H. X. Lin, Q. J. Zhao, B. Xu, and X. H. Wang, "A green synthesis of dihydropyrimidinones by Biginelli reaction over Nafion-H catalyst", Chinese Chem. Lett., Vol. 18, no. 5, p. 502-504, 2007, doi: https://doi.org/10.1016/j.cclet.2007 .03 .022

[2] R. H. Vekariya and H. D. Patel, "Alumina sulfuric acid (ASA), tungstate sulfuric acid (TSA), molybdate sulfuric acid (MSA) and xanthan sulfuric acid (XSA) as solid and heterogeneous catalysts in green organic synthesis: A review", Arkivoc, Vol. 2015, no. 1, p. 70-96, 2015, doi: 10.3998/ark.5550190.p008.894

[3] A. Rodriguez Montaña, M. H. Brijaldo, L. Rache, L. Silva, and L. Esteves, "Common Reactions of Furfural to scalable processes of Residual Biomass", Cienc. en Desarro, Vol. 11, no. 1, 2020, doi: https://doi.org/10.19053/012 17488.v11.n1.2020.10973
[4] T. J. J. Müller, "Multicomponent reactions", Beilstein J. Org. Chem., Vol. 7, p. 960-961, 2011, doi: 10.3762/bjoc.7.107

[5] Â. de Fátima et al., "A mini-review on Biginelli adducts with notable pharmacological properties", J. Adv. Res., Vol. 6, no. 3, p. 363-373, May 2015, doi: 10.1016/j.jare.2014.10.006.

[6] A. M. Niwa et al., "Salinomycin efficiency assessment in non-tumor (HB4a) and tumor (MCF-7) human breast cells", Naunyn. Schmiedebergs. Arch. Pharmacol., Vol. 389, no. 6, p. 557-571, Jun. 2016, doi: 10.1007/s00210016-1225-7

[7] M. Matias, G. Campos, A. O. Santos, A. Falcão, S. Silvestre, and G. Alves, "Synthesis, in vitro evaluation and QSAR modelling of potential antitumoral 3,4-dihydropyrimidin-2(1H)-thiones", Arab. J. Chem., Vol. 12, no. 8, p. 5086-5102, 2019, doi: https://doi.org/10.101 6/j.arabjc.2016.12.007 
[8] K. S. Atwal et al., "Dihydropyrimidine calcium channel blockers. 3. 3-Carbamoyl4-aryl-1,2,3,4-tetrahydro-6-methyl-5pyrimidinecarboxylic acid esters as orally effective antihypertensive agents", J. Med. Chem., Vol. 34, no. 2, p. 806-811, Feb. 1991, doi: $10.1021 / \mathrm{jm} 00106 \mathrm{a} 048$

[9] H. Prokopcová et al., "Structure-Activity Relationships and Molecular Docking of Novel Dihydropyrimidine-Based Mitotic Eg5 Inhibitors", ChemMedChem, Vol. 5, no. 10, p. 1760-1769, 2010, doi: https://doi.org/10.1002/ cmdc. 201000252

[10] M. K. Mishra, A. K. Gupta, and S. Negi, "AntiInflammatory Activity Of Some New Dihydropyrimidines Derivatives", Int. J. Pharm. scieences Res., Vol. 1, no. 8, p. 67-71, 2010.

[11] B. C. Raju et al., "Synthesis, structure-activity relationship of novel substituted 4H-chromen1,2,3,4-tetrahydropyrimidine-5-carboxylates as potential anti-mycobacterial and anticancer agents.", Bioorg. Med. Chem. Lett., Vol. 21 , no. 10 , p. $2855-2859$, May 2011 , doi: 10.1016/j.bmcl.2011.03.079

[12] H. A. Stefani et al., "Dihydropyrimidin-(2H)ones obtained by ultrasound irradiation: a new class of potential antioxidant agents.", Eur. J. Med. Chem., Vol. 41, no. 4, p. 513-518, Apr. 2006, doi: 10.1016/j.ejmech.2006.01.007

[13] Z. R, F. A, A. MR, M. HR, S. M, and M.A. K., "Inhibitory effect and structure-activity relationship of some Biginelli-type pyrimidines against HSV-1", Med Chem Res, Vol. 22, no. 3, p. 1270-1276, 2013.

[14] S. Chitra, D. Devanathan, and K. Pandiarajan, "Synthesis and in vitro microbiological evaluation of novel 4-aryl-5-isopropoxycarbonyl6-methyl-3,4-dihydropyrimidinones", Eur. J. Med. Chem., Vol. 45, no. 1, p. 367-371, 2010, doi: https://doi.org/10.1016/j.ejmech.2009.09 .018

[15] Suresh and J. S. Sandhu, "Past, present and future of the Biginelli reaction: A critical perspective", Arkivoc, Vol. 2012, no. 1, p. 66133, 2012, doi: 10.3998/ark.5550190.0013.103

[16] S. L. Jain, V. V. D. N. Prasad, and B. Sain, "Alumina supported MoO3: An efficient and reusable heterogeneous catalyst for synthesis of 3,4-dihydropyridine-2(1H)-ones under solvent free conditions", Catal. Commun., Vol. 9, no. 4, p. 499-503, 2008, doi: 10.1016/j.catcom.2007.04.021

[17] I. Cepanec, M. Litvić, M. Filipan-Litvić, and I. Grüngold, "Antimony(III) chloride-catalysed Biginelli reaction: a versatile method for the synthesis of dihydropyrimidinones through a different reaction mechanism", Tetrahedron, Vol. 63, no. 48, p. 11822-11827, 2007, doi: 10.1016/j.tet.2007.09.045

[18] H. Adibi, H. A. Samimi, and M. Beygzadeh, "Iron(III) trifluoroacetate and trifluoromethanesulfonate: Recyclable Lewis acid catalysts for one-pot synthesis of 3,4-dihydropyrimidinones or their sulfur analogues and 1,4-dihydropyridines via solvent-free Biginelli and Hantzsch condensation protocols", Catal. Commun., Vol. 8, no. 12, p. 2119-2124, 2007, doi: https://doi.org/10.1016/j.catcom.2007.04.022

[19] V. Polshettiwar and R. Varma, "Biginelli reaction in aqueous medium: a greener and sustainable approach to substituted 3,4dihydropyrimidin-2(1H)-ones", Tetrahedron Lett., Vol. 48, p. 7343-7346, 2007, doi: 10.1016/j.tetlet.2007.08.031.

[20] P. Salehi, M. Dabiri, M. A. Zolfigol, and M. A. Bodaghi Fard, "Silica sulfuric acid: an efficient and reusable catalyst for the onepot synthesis of 3,4-dihydropyrimidin-2(1H)ones", Tetrahedron Lett., Vol. 44, no. 14, p. 2889-2891, 2003, doi: https://doi.org/10.1016/ S0040-4039(03)00436-2

[21] M. M. Heravi, F. Derikvand, and F. F. Bamoharram, "A catalytic method for synthesis of Biginelli-type 3,4-dihydropyrimidin-2 (1H)one using 12-tungstophosphoric acid", J. Mol. Catal. A Chem., Vol. 242, no. 1, p. 173-175, 
2005, doi: https://doi.org/10.1016/j.molcata.20 05.08.009

[22] M. Moosavifar, "An appropriate one-pot synthesis of dihydropyrimidinones catalyzed by heteropoly acid supported on zeolite: An efficient and reusable catalyst for the Biginelli reaction", Comptes Rendus Chim., Vol. 15, no. 5, p. 444-447, 2012, doi: https://doi.org/10.101 6/j.crci.2011.11.015

[23] E. Rafiee, S. Eavani, S. Rashidzadeh, and M. Joshaghani, "Silica supported 12tungstophosphoric acid catalysts for synthesis of 1,4-dihydropyridines under solventfree conditions", Inorganica Chim. Acta, Vol. 362 , no. 10 , p. $3555-3562$, 2009, doi: 10.1016/j.ica.2009.03.049

[24] S. Ko, M. N. V Sastry, C. Lin, and C.F. Yao, "Molecular iodine-catalyzed one-pot synthesis of 4-substituted-1,4-dihydropyridine derivatives via Hantzsch reaction", Tetrahedron Lett., Vol. 46, no. 34, p. 5771-5774, 2005, doi: https://doi.org/10.1016/j.tetlet.2005.05.148

[25] C. Antonyraj and K. Srinivasan, "Hantzsch pyridine synthesis using hydrotalcites or hydrotalcite-like materials as solid base catalysts", Appl. Catal. A-general - APPL CATAL $A-G E N$, Vol. 338, p. 121-129, Apr. 2008, doi: 10.1016/j.apcata.2007.12.028

[26] S. Rostamnia and K. Lamei, "Diketene-based neat four-component synthesis of the dihydropyrimidinones and dihydropyridine backbones using silica sulfuric acid (SSA)", Chinese Chem. Lett., Vol. 23, no. 8, p. 930-932, 2012, doi: 10.1016/j.cclet.2012.06.008

[27] J.-L. Wang, B.-K. Liu, C. Yin, Q. Wu, and X.F. Lin, "Candida antarctica lipase B-catalyzed the unprecedented three-component Hantzschtype reaction of aldehyde with acetamide and 1,3-dicarbonyl compounds in non-aqueous solvent", Tetrahedron, Vol. 67, no. 14, p. 26892692, 2011, doi: 10.1016/j.tet.2011.01.045

[28] H. XY and X. B. W., "PEG-Promoted One-Pot Synthesis of 1,4-Dihydropyridine Derivatives
Via Hantzsch Reaction in H2O", J Kor Chem Soc, Vol. 55, p. 313-316, 2011.

[29] R. Maggi, C. G. Piscopo, G. Sartori, L. Storaro, and E. Moretti, "Supported sulfonic acids: Metal-free catalysts for the oxidation of hydroquinones to benzoquinones with hydrogen peroxide", Appl. Catal. A Gen., Vol. 411-412, p. 146-152, 2012, doi: https://doi.org/10.1016/ j.apcata.2011.10.032

[30] K. RI, I. Ahmad, K. NH, A. SHR, K. Pathak, and J. RV, "Chiral Mn(III) salen complexes covalently bonded on modified MCM-41 and SBA-15 as efficient catalysts for enantioselective epoxidation of nonfunctionalized alkenes", J. Catal., Vol. 238, no. 1, p. 134-141, 2006, doi: 10.1016/j.jcat.2005.11.042.

[31] B. R. Prashantha Kumar, P. Masih, E. Karthikeyan, A. Bansal, Suja, and P. Vijayan, "Synthesis of novel Hantzsch dihydropyridines and Biginelli dihydropyrimidines of biological interest: a 3D-QSAR study on their cytotoxicity", Med. Chem. Res., Vol. 19, no. 4, p. 344363, 2010, doi: 10.1007/s00044-009-9195-7.

[32] F. S. Falsone and C. O. Kappe, "The Biginelli dihydropyrimidone synthesis using polyphosphate ester as a mild and efficient cyclocondensation/dehydration reagent", Arkivoc, Vol. 2001, no. 2, p. 122-134, 2001, doi: 10.3998/ark.5550190.0002.214

[33] A. Debache, R. Boulcina, A. Belfaitah, S. Rhouati, B. Carboni, B. One-Pot Synthesis of 1,4-Dihydropyridines via a Phenylboronic Acid Catalyzed Hantzsch Three-Component Reaction. Synlett, 2008, 509-512.

[34] J. J. Martínez, E. Nope, H. Rojas, J. Cubillos, A. G. Sathicq, G. P. Romanelli. Dehydration of Xylose to Furfural and Its Valorization via Different Multicomponent Reactions Using Sulfonated Silica with Magnetic Properties as Recyclable Catalyst. Catalysis Letters 144, 2014, 1322-1331.

[35] P. Pratim, G. Sanjay, P.Asish, R.Das. Light induced synthesis of symmetrical and unsymmetrical dihydropyridines in ethyl lactate-water 
under tunable conditions. Tetrahedron Letters 54, 2013, 138-142.

[36] K. A. Dilmaghani, B. Zeynizadeh, M. Yari. One-pot synthesis of 3,4-dihydropyrimidin$2(1 \mathrm{H})$-ones and their sulfur derivatives with $\mathrm{H}_{2} \mathrm{SO}_{4}$ supported on silica gel or alumina. Phosphorus Sulfur Silicon Related Elem. 184, 2009, 1722-1728.

[37] L. M. Ramos, B. C. Guido, C. C. Nobrega, J. R. Corrêa, R. G. Silva, H. C. B. de Oliveira, A. F. Gomes, F. C. Gozzo, B. A. D. Neto. The Biginelli Reaction with an Imidazolium-Tagged Recyclable Iron Catalyst: Kinetics, Mechanism, and Antitumoral Activity. Chemistry: A European Journal19, 2013, 4156-4168.

Additional information: Melting point and spectral data for representative synthetized compounds

Compound 1a [1]: m.p. $155-157{ }^{\circ} \mathrm{C}$ (methanol).

${ }^{13} \mathrm{C}-\mathrm{NMR}\left(\mathrm{CDCl}_{3}, 100 \mathrm{MHz}\right): \delta=167.5,158.7$, 145.3, 140.8, 110.0, 104.4, 100.5, 59.8, 33.4, 19.3, 14.3.

${ }^{1} \mathrm{H}-\mathrm{NMR}\left(\mathrm{CDCl}_{3}, 300 \mathrm{MHz}\right): \delta=7.18(1 \mathrm{H}, \mathrm{s})$, $6.18(2 \mathrm{H}, \mathrm{s}), 5.91(1 \mathrm{H}, \mathrm{d}, \mathrm{J}=4.8 \mathrm{~Hz}), 5.18(1 \mathrm{H}, \mathrm{s})$, $4.17(2 \mathrm{H}, \mathrm{q}, \mathrm{J}=7.1 \mathrm{~Hz}), 4.12(2 \mathrm{H}, \mathrm{q}, \mathrm{J}=7.1 \mathrm{~Hz})$, $2.29(6 \mathrm{H}, \mathrm{s}), 1.24(6 \mathrm{H}, \mathrm{t}, \mathrm{J}=7.1 \mathrm{~Hz})$.

Compound 2a [2]: m.p. $150-151{ }^{\circ} \mathrm{C}$ (methanol).

${ }^{13} \mathrm{C}-\mathrm{NMR}\left(\mathrm{CDCl}_{3}, 100 \mathrm{MHz}\right): \delta=167.5,154.8$, 145.1, 140.7, 109.9, 102.6, 100.6, 39.7, 19.3, 13.3.

${ }^{1} \mathrm{H}-\mathrm{NMR}\left(\mathrm{CDCl}_{3}, 300 \mathrm{MHz}\right): \delta=7.3-7.7(5 \mathrm{H}$, $\mathrm{m}), 6.20(3 \mathrm{H}, \mathrm{m}), 5.21(4 \mathrm{H}, \mathrm{s}), 4.12(4 \mathrm{H}, \mathrm{q}, \mathrm{J}=7.0$ $\mathrm{Hz}), 2.11(6 \mathrm{H}, \mathrm{s}), 1.21(6 \mathrm{H}, \mathrm{t}, \mathrm{J}=7.0 \mathrm{~Hz})$.
Compound 3a [3]: m.p. $185-187^{\circ} \mathrm{C}$ (methanol).

${ }^{13} \mathrm{C}-\mathrm{NMR}\left(\mathrm{CDCl}_{3}, 100 \mathrm{MHz}\right): \delta=196.7,159.8$, 143.5, 140.6, 112.2, 104.2, 100.2, 57.9, 34.0, 19.4.

${ }^{1} \mathrm{H}-\mathrm{NMR}\left(\mathrm{CDCl}_{3}, 300 \mathrm{MHz}\right): \delta=7.26(1 \mathrm{H}, \mathrm{s})$, $6.40(1 \mathrm{H}, \mathrm{s}), 6.22(1 \mathrm{H}, \mathrm{s}), 5.90(1 \mathrm{H}, \mathrm{s}), 5.16(1 \mathrm{H}, \mathrm{s})$, $2.33(12 \mathrm{H}, \mathrm{m})$.

Compound 1b [4]: m.p. $208-209^{\circ} \mathrm{C}$ (methanol).

${ }^{13} \mathrm{C}-\mathrm{NMR}$ (DMSO-d $6,100 \mathrm{MHz}$ ): $\delta=165.4$, 155.8, 152.3, 149.6, 142.2, 110.3, 105.3, 96.5, 50.8, 47.5, 17.7 .

${ }^{1} \mathrm{H}-\mathrm{NMR}$ (DMSO-d $\left.6,300 \mathrm{MHz}\right): \delta=9.25(1 \mathrm{H}$, s), $7.76(1 \mathrm{H}, \mathrm{s}), 7.54(1 \mathrm{H}, \mathrm{s}), 6.34(1 \mathrm{H}, \mathrm{m}), 6.08(1 \mathrm{H}$, $\mathrm{d}, \mathrm{J}=2.8 \mathrm{~Hz}), 5.18(1 \mathrm{H}, \mathrm{d}, \mathrm{J}=3.2 \mathrm{~Hz}), 3.55(3 \mathrm{H}, \mathrm{s})$, $2.22(3 \mathrm{H}, \mathrm{s})$..

Compound 2b [5]: m.p. $209-211{ }^{\circ} \mathrm{C}$ (methanol).

${ }^{13} \mathrm{C}-\mathrm{NMR}$ (DMSO-d $6,100 \mathrm{MHz}$ ): $\delta=165.1$, $155.8,152.4,149.1,142.0,110.3,105.1,96.8,59.2$, $47.8,17.7,14.2$.

${ }^{1} \mathrm{H}-\mathrm{NMR}$ (DMSO-d $\left.6,300 \mathrm{MHz}\right): \delta=9.27(1 \mathrm{H}$, s), $7.74(1 \mathrm{H}, \mathrm{s}), 7.54(1 \mathrm{H}, \mathrm{s}), 6.34(1 \mathrm{H}, \mathrm{s}), 6.08(1 \mathrm{H}$, s), $5.20(1 \mathrm{H}, \mathrm{s}), 4.02(2 \mathrm{H}, \mathrm{q}, \mathrm{J}=7 \mathrm{~Hz}), 2.20(3 \mathrm{H}, \mathrm{s})$, $1.11(3 \mathrm{H}, \mathrm{t}, \mathrm{J}=7 \mathrm{~Hz})$.

Compound 3b [4]: m.p. 205-208 ${ }^{\circ} \mathrm{C}$ (methanol).

${ }^{13} \mathrm{C}-\mathrm{NMR}\left(\mathrm{DMSO}_{\mathrm{d}}, 100 \mathrm{MHz}\right): \delta=183.4$, $165.5,154.5,146.4,142.8,110.7,106.4,106.0,51.4$, $47.8,17.3$.

${ }^{1} \mathrm{H}-\mathrm{NMR}$ (DMSO-d $\left.6,300 \mathrm{MHz}\right): \delta=10.41(1 \mathrm{H}$, s), $8.94(1 \mathrm{H}, \mathrm{s}), 7.56(1 \mathrm{H}, \mathrm{s}), 6.35(1 \mathrm{H}$,

$\mathrm{m}), 6.14(1 \mathrm{H}, \mathrm{d}, \mathrm{J}=2.8 \mathrm{~Hz}), 5.20(1 \mathrm{H}, \mathrm{d}, \mathrm{J}=1.2$ $\mathrm{Hz}), 3.76(3 \mathrm{H}, \mathrm{s}), 2.25$ (3H, s). 